\title{
A Conceptual Metaphor Account of Desdemona: Body, Emotions, Ethics
}

\author{
Miriam Mezghani ${ }^{1}$ \\ ${ }^{1}$ Department of English, Higher Institute of Science applied to Humanities of El Kef, University of Jendouba, \\ Tunisia \\ Correspondence: Miriam Mezghani, Department of English, Higher Institute of Science applied to Humanities of \\ El Kef, University of Jendouba, Tunisia. E-mail: miriam.mezghani@yahoo.com
}

Received: March 3, 2021 Accepted: April 10, 2021 Online Published: April 19, 2021

doi:10.5539/ells.v11n2p20 URL: https://doi.org/10.5539/ells.v11n2p20

\begin{abstract}
This paper aims to delve into Desdemona's mind in Shakespeare's Othello. In this paper, Desdemona's utterances are perused through conceptual metaphor analysis. The objective of this study is to disclose Desdemona's cognitive complexity, and conceptual metaphor analysis offers an opportunity to enter Desdemona's cognitive world notwithstanding the degradation of her speech. These conceptual metaphors will follow three major axes of scrutiny: body, emotions, and ethics. The findings of this paper demonstrate that a cognitive exploration of the character reveals a structured system of thoughts where corporeal passions, emotional acuity, and ethical choices are culminated in a coherent and dynamic female protagonist. Desdemona's conceptual metaphors confirm a sensual and wilful persona who broke an ascetic image of femininity associated with conditioning and interdictions. The study aspires to demonstrate how Desdemona would become a haunting presence on stage, triumphant even as all other characters fell, and how she would reach from beyond the grave to hold the audience in the throes of empathy. The intent of the paper is also to point out that conceptual metaphor analysis, with its ties to cognitive poetics, can furnish character criticism with dissimilar readings.
\end{abstract}

Keywords: conceptual metaphor analysis, Desdemona, body, emotions, ethics

\section{Introduction}

A pillar of the English Renaissance, William Shakespeare wrote masterpieces in literature. After 400 years, he is still a pivot for fierce debates and discussions. Shakespeare is quoted in political speeches and popular advertisements, modernized in movies and theatres, and written about in books and articles. His works seem to draw from bottomless themes which are at the heart of contemporary debates. One of his most relevant and cardinal plays is Othello. The tragedy is based on an Italian short story by Giraldi Cinthio. Othello was performed in 1604 by the King's Men at the court of James I. The play is about a young and noble Venetian woman, Desdemona who elopes with Othello, an older black Moorish general and marries him without the blessings of her father and family. Their true love is quickly compromised when Iago's whispers of treachery and deceit are believed. Othello's composure and forbearance are eroded with doubt and hate once he becomes convinced of his wife's treacherous actions. In an attempt to regain his honour, Othello strangles Desdemona for her supposed love affair with his lieutenant Cassio. Once the truth is revealed, he commits suicide out of grief and despair.

As the play draws its curtains, the audience is left with a sinister final scene littered with dead bodies and fragmented words. Indeed, the injustice of the heroine's demise seems to crowd the stage. She becomes the lacuna in the play; a chasm dense with other possible outcomes. Abbott (2015) declares that to "end with a still is to end with a photograph - a moment of action, assuredly but a fixed memoir of a moment now firmly in the past" (p. 111). One can add that this stillness in Desdemona's death scene is further titillated by the body hidden behind the bed curtains. Her tragic heroism is magnified by its own ubiquitous stillness and omission. As other characters invade the stage and while other stories unfold, Desdemona's voice remains a focal point of attention making all other narratives futile and meaningless. What might have happened if Desdemona had been granted the space to speak and refute accusations of infidelity? What might have happened if she had been able to provide her own ocular proof that she did not "trespass 'gainst his love [Othello] either in discourse of thought or actual deed" (4.2.153-154)? 
Within the cultural context of the Renaissance, one might wonder how to live under the crushing presence of patriarchy (Drakakis, 1992; Stone, 1990; Loomba, 1989; Stallybrass, 1982). As a dominant voice, the latter gains the privilege not only to monopolize cultural references and political bodies; also it chooses who can be included in discourse and who must be excluded from it. The patriarchal figure is omniscient, omnipresent, and omnipotent. Women are potential sites of resistance that the totalitarian voice will rush to colonize and neutralize within fabricated frames of imposed chastity and submission. Belsey (1985) advances that "to be a subject is to speak, to identify with the 'I' of an utterance, to be the agent of the action inscribed in the verb" (p. 15). Thus, to ideologically implode patriarchal networks, Desdemona needs to verbalize and conceptualize her own rhetoric of identity. To found a distinct identity is to fashion a separate and subversive subject position. Evans (2015) advances that "speakers come to own their speech and belong to what they say" (p. 20). Accordingly, one would wonder if conceptual metaphors allow Desdemona to foster acts of resistance. Would her conceptual metaphors express verbal and mental subversive messages? Would they provide tools to reform the feminine body, to speak desires and passions, and to verbalize power from within?

Therefore, this study proposes to scrutinize Desdemona's untold stories by deconstructing her mind through conceptual metaphor analysis. There are three major objectives to fulfill: first, to document the extent to which conceptual metaphor analysis can unveil Desdemona's interiority; second, to determine how her perception of her body, affective turmoil, and ethical beliefs reflect a dissident voice.

\section{Conceptual Metaphor Analysis and Literary Interpretation of Desdemona}

Interest in metaphors can be traced back to Aristotle and Plato (Stockwell, 2002; Ortony, 1993). The emergence of different literary schools expands its understanding of metaphors beyond classical definitions. Old designations were questioned while new ones were adopted. Traditionally, metaphors go back to the Aristotelian philosophy. In the Rhetoric, Aristotle defines metaphors using the term 'defamiliarizing language' (p. 10). He explains that a metaphor is created when "giving the thing a name that belongs to something else" (p. 8). Technically, a metaphor is defined as the association of unconventional attributes between two entities, which share some common traits. It is a figure of speech and a process of comparison. Thus, a metaphor is a matter of language through which it gains an ornamental layer in discourse. Schwarz (1997) remarks that "Roman rhetoricians emphasized the use of metaphor to promote a sublime style for the expression of noble thoughts" (p. 21). The insistence upon the lofty and exclusive nature of metaphors to literature will be cemented through time until the 19th century.

The definition of the metaphor took a new course with cognitive approaches. In their book, Metaphors We Live By (1980), George Lakoff and Mark Johnson inaugurated the foundations of Conceptual Metaphor Analysis. They promote the idea that metaphor is about thought more than grammar or linguistics. It is the transcription of the mind's conception of the world. Kovecses (2020) advances that

"the main aim of Conceptual Metaphor Theory is to analyze and describe the conceptual nature of metaphors: how conceptual metaphors structure thought, how they enable inferences, how they can give us new perspectives on reality, how they can construct new ideas and concepts, how they are grounded in experience, and so on" (p. 9).

In other words, people do not define the world through metaphors. They actually understand the world by knitting a conceptual net of that world.

Technically, Lakoff and Johnson (1980) contend that a conceptual metaphor is the mapping from a concrete source domain to an abstract target domain. To further explain this theory, they give the following example in the context of a dating couple: "“it's been a long bumpy road"” (p. 206). According to this example, the metaphorical concept is 'LOVE IS A JOURNEY' where the source domain is journey and the target domain is love. Kovecses (2010) defines the notion of mapping in the following terms: "There is a set of systematic correspondences between the source and the target in the sense that constituent conceptual elements of $\mathrm{B}$ correspond to constituent elements of A. Technically, these conceptual correspondences are often referred to as mappings" (p. 7). So conforming to the example presented above, love is the abstract target domain. It is conceptualized in terms of a concrete source domain, which is journey. Hence, it can be said that love traits become those of a journey; it needs organization, supplies, a means of transportation, and a compass. The speaker will have to cooperate with his partner to reach their final destination.

Moreover, a conceptual metaphor is composed of a linguistic expression and a conceptual frame. Lakoff and Johnson (1980) explain the linguistic expression as a "word, phrase, or sentence that is the surface realization of such a cross domain mapping" (p. 203). Kovecses (2010) defines the conceptual form as "ways of thinking" (p. 8) manifested and revealed into existence through the linguistic expression of the metaphor. To illustrate, he 
provides the following example: as a linguistic expression "she devoured the book" (p. 28) while the conceptual metaphor is "IDEAS ARE FOOD" (p. 28). However, occasionally, there may be conceptual metaphors that have no linguistic metaphors to express them (Kovecses, 2010, p. 27). For instance, the concept PROBLEMS ARE PHYSICAL WEIGHT (Kovecses, 2010, p. 101) can be expressed on a stage or by a character in a play through the way he walks: heavy steps, hunched back, and dropping shoulders. The image conveys that problems are a burden on one's body and mind.

As mentioned before, some linguistic expressions are the starting point for other conceptualizations that can be inferred through numerous mappings or suppositions. Conceptual metaphors are grounded in human experience and language. Both are flexible and fluid notions that expand the meaning of the metaphors. Kovecses (2010) calls the phenomenon "metaphoric entailment" (p. 11). The mapped spaces or domains can derive further relationships and source-target knowledge can be extended and enriched. For instance, the example JULIET IS THE SUN can lead to the metaphoric inference that Juliet is warm, luminous, and a source of life for Romeo. Indeed, the sun transfers its qualities to Juliet. In this context, Monika Fludernik (2010) points out that conceptual metaphors may be "semantically enriched constructs" birthing "new meanings not contained in either the source or target domain" (p. 10). To illustrate this idea, Fludernik uses a cartoon published during the American presidential campaign in which Obama and his adversary MaCain are dressed as cowboys, shooting at each other with pistols. She comments that the cartoons can be read as "an implied denigration of Obama (qua villain cowboy or Indian)" or as a criticism of MacCain's "subconsciously racist attitude towards his antagonist" (p. 11). Accordingly, the conceptual metaphor POLITICS IS CONFLICT transcends itself and proliferates to include other mental constructs such as race and tolerance.

With nascent academic interest in interdisciplinary approaches to literature, old boundaries are dissolving. Various disciplines that range from linguistics, to cognitive studies, to sociology and psychology became involved with elements of literature. It is impossible to provide an exhaustive account of the scholarly work conducted on conceptual metaphor. However, one can survey a list of some relevant research related to the context of this paper. Accordingly, a number of studies have adopted conceptual metaphor analysis to studying Shakespearean plays. In "Metaphor in Literature", Semino and Steen (2008) observe that "the use of metaphor in individual plays has received comparatively less attention, with the notable exception of Shakespeare's works" (p. 240). Both attribute the most influential studies in the field to Donald Freeman who uses conceptual metaphor analysis to investigate three major Shakespearean plays: King Lear (1993), Macbeth (1995), and Antony and Cleopatra (1999). In more recent research, Oncins-Martinez (2007) adopts conceptual metaphor analysis to conduct a perusal of Shakespeare's sexual language in the bulk of his plays. Jennifer McDermott (2014) uses conceptual metaphor analysis to argue that conceptual mappings between body and affect in Othello serve to foster particular feelings in the audience. While there is an extensive academic foray into conceptual metaphor analysis as a discipline, the theory's adaptations to a theatrical corpus are moderately limited. There are still unchartered terrains that call to be explored when it comes to applying conceptual metaphor analysis to literature.

In conjunction with the examples cited above, conceptual metaphor analysis seems to be suitable to dramatic texts. Drama is a particular genre because of its directness. There is no narrator to run interference between the audience/reader and the characters. With Shakespeare, this candour becomes even more acute since the dramatist uses few if barely stage directions. The protagonists' speech becomes representational in that words instantiate mental spaces that provide access to the characters mind style. Fowler (1996) defines mind style as "the world-view of an author, or a narrator, or a character, constituted by the ideational structure of the text" (p. 21). Desdemona is a pillar character in Othello. Her importance does not reside in her role as a catalyst for action in the play but on the way she is used conceptually by other characters. She is the focal point of conflicting inner narratives. Under the grind of Rodrigo's desires, Iago's perversions, and Othello's jealousies, reading Desdemona's mind would liberate her from these encroaching impressions.

In the light of the foregoing discussion, one might inquire about the choice to found the core of the study on Desdemona's character. In fact, she has been the center of continuous curiosity and interest within the scholarly community. From Mary Cowden Clarke's The Girlhood of Shakespeare's Heroines in the 19th century to Toni Morrison's Desdemona in the 21st century, several attempts were made to allow her words to come to life and be heard. Othello opens with a Desdemona locked in a 'world of sighs' at Othello's 'wondrous' tales. At the end of the play, all of her sighs are smothered and withered into death. She is an obsession, a possession, and an offence. This absence of interiority seems to characterize Shakespearean female heroines (Barker, 1995; Belsey, 1985). Whatever her position in discourse is, Desdemona is one of those who are devoured in the tragedy. Paris (2009) comments that when it comes to Desdemona "many critics have been struck by the disparity between her 
assertive behaviour early on the play and her inability to defend herself later" (p. 95). In his Faultlines, Sinfield writes about her complete lack of subjectivity. He argues that Desdemona displays through the tragedy's scenes different personalities that are unexplainably broken. She is a bold woman who elopes with her lover and eloquently defends her rights to make decisions for herself. Then, she transforms into a shrewish meddlesome wife who tries to manage her husband's political affairs:

"My lord shall never rest,

I'll watch him tame, and talk him out of patience;

His bed shall seem a school, his board a shrift" (3.3.22-24).

The play closes with a weak powerless victim who easily submits to Othello's rage, all former boldness gone.

In the same vein, Slater (2019) claims that "in the patriarchal world of Othello, Desdemona marks a site of contest. Suspended between father and husband, Venice and Cyprus, domestic and public, her character is largely a function of place and obedience, and her relation to both is obscure" (p. 215). Hence, what is relevant about the use of conceptual metaphor analysis is that it aims to dissipate this obscurity that surrounds her character. It attempts to excavate the traces of Desdemona's disobedient voice from the reputably silent Shakespearean text itself. Kovecses (2020) comments that a metaphor is "not simply an ornamental device in language but [is] a conceptual tool for structuring, restructuring, and even creating reality" (p. 1). Conceptual metaphor analysis offers to refute the idea that Desdemona is an adrift signifier whose signified is inscribed by external forces. She successfully recreates reality, breaks the fetters of patriarchy, and weaves a dissident self into the intricate fabric of the play.

\section{Desdemona Conceptual Metaphors of the Body}

In Othello, Desdemona's body is turned into a political emblem. When she gives her body to her lover without the consent of her father, Brabantio loses his faith in all women "for your sake jewel, / I am glad at soul I have no other child; / For thy escape would teach me tyranny" (1.3.193-95). Iago capitalizes on patriarchal obsession with female sexuality to entrap Othello in jealousy and turmoil "I'll pour this pestilence into his ear" (2.3.336). Othello reduces Desdemona's body into a monolithic interpretation of sexuality which is whoredom and sin. Karim-Cooper maintains that "imagining the woman as text was not uncommon in early modern writing" (p. 147). In the play, Othello asks Desdemona "was this fair paper, this most goodly book made to write 'whore" upon?" (4.2.73). Accordingly, Othello assimilates the body to a book and sexuality becomes a text that is rewritten and reread according to masculine insecurities and anxieties. Othello's obsession with Desdemona's body breaks his mind and drives him to murder:

"Lie with her? Lie on her? We say lie on her when they belie Her. Lie with her! Zounds, that's fulsome! Handkerchief Confessions - handkerchief! To confess and be hanged for his Labor. First to be hanged and then to confess" (4.1.35-39).

Towards the end of the play, Othello asks Desdemona "what art thou?" (4.2.34; Emphasis added) instead of "who art thou?". This syntactic deviation reflects the irresolute nature of the feminine body in the linguistic contradiction between "what" that denotes objects and "thou" which denotes personhood.

In this amalgamation of misconceptions, Desdemona wrestles the words to craft her own definition of the female body in her exchanges with Othello. The table below is a qualitative examination of conceptual metaphors present in Desdemona's speech pertaining to the body. The first column will provide textual references. The second column corresponds to conceptual metaphorical constructs which are capitalized according to Lakoff and Johnson's requirements. The symbol “*” designates entailed conceptual metaphors. The table will be complemented with a literary interpretation of the findings. The same pattern will be adopted with the following tables in this study. 
Table 1. Desdemona's conceptual account of the body

\begin{tabular}{ll}
\hline Reference & Conceptual Metaphor \\
\hline I saw Othello's visage in his mind (1.3.248) & PHYSICAL FEATURES ARE IDEAS \\
& MIND IS MIRROR * \\
& SEEING IS KNOWING * \\
& IDENTITY IS A MENTAL STATE * \\
It [Desdemona's hand] yet hath felt no age, nor known no sorrow (3.4.33) & FEMALE'S BODY PART IS A WHOLE PERSON \\
For twas that hand that gave away my heart (3.4.41) & A FEMALE'S BODY PART IS AN AGENT \\
& A PERSON IS A HEART \\
$\begin{array}{ll}\text { If to preserve this vessel for my lord from any other foul unlawful touch be } \\
\text { not to be a strumpet, I am none (4.2.83-85) }\end{array}$ & A FEMALE BODY IS A CONTAINER \\
\hline
\end{tabular}

In a morbid blazoning of Desdemona, Othello breaks her body into blood, skin, breath, and lips. She is alabaster, snow, and a plucked rose. Fox (2013) contends that "the blazon verbally enacts the disintegration of the female body under the controlling gaze of the male subject, ensuring that the threat of her subjectivity is neutralized" (p. 198). This dissemination of the body in Othello is aborted when Desdemona claims that a FEMALE'S BODY PART IS A WHOLE PERSON. She conceptually imparts the attributes of the whole into the parts. The female body becomes an uncountable and coherent entity that cannot be dissociated into fragments. The body's capacity to feel and think is suffused into its totality. This impermeability to a fracturing discourse is further emphasized in the schema A FEMALE BODY PART IS AN AGENT as feminine will is affirmed. Desdemona's body is not merely a vehicle of actions but also a source of volition and thoughts as the concept SEEING IS KNOWING entails. In his attempts to explain the relationship between seeing and knowing, Barry Stroud observes "seeing is described in a sentence in which the complement of the perceptual verb 'see' is a sentence with a truth value, not a singular term referring to an object" (87). Accordingly, Desdemona's perceptual experience of the world is what initiates thinking. In the utterance "I saw Othello's visage in his mind" (1.3.248), truth value resides in the idea that the body is defined in cognitive terms and not through immediate physical attributes. The conceptual metaphor PHYSICAL FEATURES ARE IDEAS embeds the body in the mind. Thus, Desdemona abolishes the barriers of skin and cognitive perception extends and encroaches on social order.

By designating identity as a mental state, Desdemona wields acceptance and substitutes comfort over anxiety and rejection. Race and gender by association are turned into ideological constructs which are independent from their physical forms. They are only visible in the mind as invoked in the conceptual metaphor THE MIND IS A MIRROR. The speaker liberates the body from xenophobia and misogyny, relocating it from the realm of the concrete to the realm of fluid abstraction. Whether feminine or black, Desdemona conceptualizes the body as self-motivated and self-representing. She mentally projects a refined sense of feminine volition that stems not only from the heroine's consciousness but also from its physical shape. Desdemona humanizes the body that patriarchy has objectified and vilified. Her dissidence resides in this elevation that departs from a denigrating value system in which a woman's body is located at the fringe of her being.

Additionally, Desdemona uses the concept A FEMALE BODY IS A CONTAINER in her speech. Lakoff (1987) consider that "a container schema, on a standard cognitive account, consists of a boundary distinguishing an interior and an exterior" (p. 271). The concept marks Desdemona's need to introduce her body as a separate entity from a hegemonic external patriarchal consciousness that classifies womanhood in form and in essence. The body as a container becomes the boundary and the repository of emotions, sexuality, and beliefs. It is also a protector, a limit that aims to "preserve" (4.2.83) what it carries. The container schema also invokes a powerful religious iconicity to the female body. Desdemona sanctifies the feminine body as she claims

\section{"No, as I am a Christian}

\section{If to preserve this vessel for my lord}

From any other foul unlawful touch

Be not to be a strumpet, I am none" (4.2.83-85; emphasis added).

The utterance has various biblical connotations. Desdemona mentally reiterates the biblical line "if anyone cleanses himself from these things, he will be a vessel for honor, sanctified, useful to the Master" (2 Timothy 2:21). Culturally, in the Renaissance, God's commandments are the standards to determine lawful and unlawful touching. The interplay in the use of the expression "my lord" with its double significance-sacred and secular-lexically, seems to refer to God in the utterance. Therefore, the 'vessel' as a holy Christian utensil is extended to include Desdemona's body. These mappings appeal to powerful sacramental imageries that moor the 
female body within a religious experience of salvation as she declares "I shall be saved" (4.2.87).

Tita Baumlin (2009) advances that "the Renaissance construction of ideal womanhood prescribed for female behaviour three interlocking cardinal virtues: chastity, obedience and silence" (p. 144). Desdemona breaks one of these covenants when she decides to follow her husband to war in Cyprus. Her foray into the world of men casts over the feminine body suspicions of illicit libidinous desires. However, having a voice seals her fate even before Iago's machinations come into fruition as she flaunts her disobedience of social orders. In fact, Desdemona's interpretation of the female body is not only exclusive to its corporeal dimension. It also includes concepts of the body as a voice. The body speaks and manipulates language. Hence, feminine discourse is a continuity of the body that produces it. The table below explores Desdemona's perception of her voice:

Table 2. Desdemona's conceptual account of her voice

\begin{tabular}{ll}
\hline Reference & Conceptual Metaphor \\
\hline Alas she [Emilia] has no speech (2.1.105) & FEMININE SPEECH IS A POSSESSION \\
My advocation is not now in tune (3.4.118) & FEMININE SPEECH IS MUSIC \\
& FEMININE SPEECH IS DISSONANCE * \\
& FEMININE SILENCE IS HARMONY * \\
And Stood within the blank of his displeasure for my free speech (3.4.122-123) & FEMININE SPEECH IS FREEDOM \\
& TO SPEAK IS TO BE PUNISHED * \\
If e'er my will did trespass 'gainst his love either in discourse of thought or & SPEAKING IS FELONY \\
actual deed (4.2.154-155) & \\
\hline
\end{tabular}

Looking at the table, there are two colliding conceptual configurations that emerge. The masculine subject mentally constructs the feminine voice as: FEMININE SPEECH IS DISSONACE, FEMININE SILENCE IS HARMONY, TO SPEAK IS TO BE PUNISHED, and SPEAKING IS FELONY. On the other hand, Desdemona conveys the mental images that FEMININE SPEECH IS A POSESSION, FEMININE SPEECH IS MUSIC, and TO SPEAK IS TO BE FREE. Desdemona seems to be aware that patriarchy is constantly negotiating and inscribing limitations to her ability to speak. Her voice cannot rise beyond a consented verbal space.

For instance, the conceptual metaphors FEMININE SPEECH IS DISSONANCE and FEMININE SILENCE IS HARMONY denote that, to belong to the dominant music of the group, Desdemona needs to be a mute. Yet, by choosing to voice her opinions, she willingly exalts dissonance over harmony "you must awhile be patient: what I can do, I will; and more I will" (3.4.127-28). It is only through irrelevant tunes that the heroine transforms from an eerie object of adoration to visibility and attention. By talking out of turn, she dispels the auditory simulacrum of patriarchal harmony that used to edit and erase scratchy feminine voices as the encounter shows:

Desdemona: [...]Good love, call him back.

Othello: Not now sweet Desdemona; some other time.

Desdemona: But shall't be shortly,

Othello: The sooner, sweet, for you.

Desdemona: Shall't be tonight at supper?

Othello: No not tonight;

Desdemona: Tomorrow dinner then?

Othello: I shall not dine at home: I meet the captains at the citadel. (3.3.56-64)

Desdemona's insistence to pursue Cassio's matter against her husband attempts to reject her demand marks the beginning of a dissonant interaction between the spouses for the rest of the play. Forthwith, when she pierces the synchronization of masculine music, the female protagonist provokes irritation, incredulity, and even cavernous existential anxieties since discordance negates harmony and brings chaos and change to order and stability as Othello rails:

"I think my wife be honest, and think she is not

I think that thou art just, and think thou art not" (3.3.385-86).

By professing cognitive awareness of an oppressive cultural voice, Desdemona claims along the repercussions of a loud speaking ' $I$ ', dispelling allegations of a naive and self-deluded heroine. Indeed, there is a penalty for feminine discourse. The conceptual metaphors, TO SPEAK IS TO BE PUNISHED and SPEAKING IS FELONY, 
pit feminine choice against masculine discipline. Desdemona's unhinged discourse incurs patriarchal ire and she is exiled into a no man's land as she says "and stood within the blank of his displeasure for my free speech" (3.4.126). Feminine discourse is a path to the void and words that engender existence become words of absence and blankness. Once she refused to be tongue-tied, the heroine has embarked on a perilous journey where she valorises resistance over submission. She shifts focus from her physical alienation to her verbal alienation highlighting the intentionality to fissure these walls of confinement.

\section{Desdemona's Conceptual Metaphors of Emotions}

Othello stands at the vortex of violent emotions; debilitating jealousy, envy that degenerates into mayhem, shame that aggravates and destabilizes, love that kills and self-destructs, and desire that is tainted with revenge and fear. For many characters, these emotional movements are expanded and revealed in soliloquies and monologues, allowing Othello and Iago fluid expressions of affective states. On the other hand, Desdemona's emotions are inaccessible in the world of the play. She is given no soliloquies. Theatrically, her character delivers six monologues which frequency decreases as the play unfolds. At the opening of the tragedy, Brabantio describes his daughter as a

$$
\text { "maiden never bold }
$$

of spirit so still and quiet that her motion

Blushed at herself" (1.3.94-95).

His words imply Desdemona's inability to display any sort of affective distinctiveness. It is a static portrait of Desdemona that denies her emotions, motion, and by consequence life. Thus, one of the purposes of this study is to refute this emotional penury and reveal the heroine's plethora of emotions through conceptual metaphor analysis.

Actually, understanding Desdemona's emotions is a prerequisite to understanding her character. Paster argues that "the history of the embodied emotions is also a history of ways of inhabiting the world" (8). He asserts that emotions as a medium that react and interact with the world are entrenched in the body as well as in the social and cultural context that surrounds them. Accordingly, to inhabit the world refers to an ontological geffort to carve a physical space within it and to establish an individual affective experience of how the world is constructed. While navigating the troubled waters of her marriage, Desdemona will question age-old cautionary tales against the treacherous and mercurial passions that plague women and render them untrustworthy and irrational. The Conceptual Metaphors displayed in the table below open a door into an interpretive reading of Desdemona's emotions:

Table 3. Desdemona's conceptual account of emotions

\begin{tabular}{|c|c|}
\hline Reference & Conceptual Metaphor \\
\hline \multirow[t]{4}{*}{ My heart subdued even to the very quality of mu Lord (1.3.246) } & LOVE IS WAR \\
\hline & LOVE IS SURRENDER * \\
\hline & LOVE IS DEFEAT * \\
\hline & HEART IS A WARRIOR * \\
\hline $\begin{array}{l}\text { And to his honors and his valiant parts did did I my soul and fortunes consecrate } \\
\text { (1.3.249-50) }\end{array}$ & LOVE IS SACRED \\
\hline \multirow{3}{*}{$\begin{array}{l}\text { I be left behind a moth of peace, and he goes to the war the rites for which I love him are } \\
\text { bereft me (1.3.251-53) }\end{array}$} & LOVE IS OWNERSHIP \\
\hline & LOVE IS RITUALS * \\
\hline & LOVE IS A PURPOSE * \\
\hline \multirow{7}{*}{$\begin{array}{l}\text { When I have a suit where in I mean to touch your love indeed, it shall be full of poise and } \\
\text { difficult weight (3.3.80-82) } \\
\text { I was unhandsome warrior as I am, arraigning his unkindness with my soul; but now I find } \\
\text { I had suborn'd the witness, and he's indicted falsely (3.4.151-54) }\end{array}$} & LOVE IS A PHYSICAL OBJECT \\
\hline & LOVE IS A BURDEN \\
\hline & EMOTIONS ARE LITIGATIONS \\
\hline & LOVE IS WAR \\
\hline & LOVE IS INDICTMENT * \\
\hline & UNKIND BELOVED IS ARRESTED OFFENDER * \\
\hline & LOVER'S LIFE IS COURT PROCEEDINGS * \\
\hline What shall I do to win my lord again? (4.2.149) & LOVE IS WAR \\
\hline $\begin{array}{l}\text { If e'er my will did trespass' gainst his love either in discourse of thought or actual deed or } \\
\text { mine eye, mire ears, or any sense delighted them in any other from }(4.2 .151-54)\end{array}$ & LOVE IS OWNERSHIP \\
\hline \multirow[t]{2}{*}{ Some bloody passion shakes your very frame (5.2.44) } & EMOTIONS ARE VIOLENCE \\
\hline & EMOTIONS ARE A NATURAL FORCE * \\
\hline \multirow[t]{2}{*}{ Oh my fear interprets! (5.2.74) } & EMOTIONS ARE KNOWLEDGE \\
\hline & EMOTIONS ARE ANIMATE BEINGS * \\
\hline
\end{tabular}


Love is the dominant emotion that Desdemona tends to express in her conceptual metaphors and it is mapped with two experiential dimensions, battleship and law, as the figure below summarizes:

\begin{tabular}{l|l}
$\quad$ Battleship & \multicolumn{1}{c}{ Law } \\
LOVE IS WAR (repeated 3 times) & EMOTIONS ARE LITIGATIONS \\
LOVE IS SURRENDER & LOVE IS INDICTMENT \\
LOVE IS DEFEAT & UNKIND LOVE IS ARRESTED OFFENDER \\
HEART IS WARRIOR & LOVER'S LIFE IS COURT PROCEEDINGS \\
EMOTIONS ARE VIOLENCE &
\end{tabular}

Desdemona's mental schemas of love are built over alien domains since war and justice are masculine privileges in the Renaissance. Jennifer Vaught asserts that during early modern England "men often express their emotions stoically or moderately, or vent intense emotions through violent actions" (4). She adds that meanwhile women "were thought to possess less innate ability to control their emotions" (8). However, Desdemona shatters this dichotomy when she appropriates forms of masculine expressions of emotions by adopting the conceptual metaphor LOVE IS WAR. The affective interplay between reason and aggressivity subverts conventional representations of women in love, being neither modest nor coy. Her emotional display of passion towards her husband or even her friends such as Cassio is structured by the concept of war and its entailments. Desdemona perceives love as dynamic and active. She is not a pursued but equally a pursuer. She strategizes the purposes for this war. Winning is succeeding in securing Othello's support in her endeavors for Cassio's suit as well as restoring his affections towards her.

Construing love within the domain of war might paint Desdemona as hysterical, unreasonable, and vicious in her passions. Kovecses (2003) maintains that "control, in the realm of emotion at least, can be broken down into three parts, or stages: attempt at control, loss of control, and lack of control" (p. 43). Even though Desdemona conceptualizes love in the violent events of war, she claims a rational self that governs her actions and intentions. One can assume that mapping love into the concept of law indicates Desdemona's adherence to self-control. Mentally, she fits violent emotions into a universe ruled by reason as in the conceptual metaphors EMOTIONS ARE LITIGATIONS and LOVE IS INDICTMENT. Love is deliberated within a judicial system that prevents chaos and oppression as it is reflected in the schema UNKIND LOVE IS ARRESTED OFFEDER. The desire to order her emotional bursts reflects Desdemona's desire to rearrange an external world that Othello has sent into disarray as she finally understands "alas, he is betrayed and I undone" (5.2.77).

Likewise, Desdemona seems to realize that, unlike her, Othello's emotions are brutal forces, distorting his perception of the world. The conceptual metaphor EMOTIONS ARE NATURAL FORCES intimates her awareness that uncontrollable emotions are destructive of the self and the other. Unruly affections have displaced Othello's rational mind, clouded his judgment, and spilled to infect his relationship with the world. Ironically, excessive passions are conventionally associated with female experiences. Paster comments that Early Modern era regarded women's passions as just another term for "The emotional volatility of inconstancy [that] seems to be a threat, rather than an incentive, to the production of individuality in speech and action" (80). In the wake of an evanescent Othello, Desdemona remains unified. In opposition to patriarchal ideology, she appears to believe that emotional forces if controlled are capable of higher mental functions as she thinks that EMOTIONS ARE KNOWLEDGE. The concept that the heart is the seat of emotions is destabilized by Desdemona who relocates emotions into the mind; emotions that produce and are produced by knowledge.

Wehrs (2017) comments that affect "destabilizes modalities of embodiment (nature) constituted by linguistically mediated conceptualities, ideologies, and psychicbodily formations (nurture)" (p. 39). Indeed, for Desdemona, emotions are an anchor for inner consistency. When she was confronted with Othello's wild passions and broken language, Desdemona's feelings were her only compass in a sea of disordered words and muddled meanings " $O$, my fear interprets!" (5.2.75). In Rhetorical Power, Mailloux (1989) argues that "interpretation always creates the signifying text, that meaning is made, not found" (p. 5). Metaphorically, Desdemona's emotions enable her to understand and contextualize Othello's discourse "I understand a fury in your words" (4.2.31-32). Pickavé and Chapiro (2012) remark that the Renaissance followed a "long tradition of taking emotions as both opposed to reason and rational thought" (p. 1). The concept that EMOTIONS ARE KNOWLEDGE is a challenge to a system that stifles affective exhibitions claiming a perpetual conflict between the rational self and the emotional self. Thus, one can assume that for Desdemona emotions are meaning-making filters that attribute and allocate significance to a world of "foregone conclusions" (3.3.431). 


\section{Desdemona's Conceptual Metaphors of Ethics}

While navigating emotions and their associations, Desdemona also subtly binds her actions to ethical motivations in Othello. In the tragedy, Othello tells Iago:

"to say my wife is fair, feeds well, loves company,

Is free of speech, sings, plays, and dances well;

where virtue is, these are more virtuous" (3.3.187-189).

Yet, the more the world of Othello unfolds, the more Desdemona is stripped back almost to nothing. Her virtue hailed by Othello at the beginning of the play is shattered by a primeval belief that all women are immoral:

"tis destiny unshunnable, like death:

Even this forked plague is fated to us when we do quicken" (3.3.278-279).

In Doctrine for the Lady of the Renaissance, Kelso maintains that the moral ideal for a man is "self-expansion and realization [...] for the lady the direct opposite is prescribed" (p. 6). As patriarchy denies moral equality between men and women, conceptual metaphor analysis shows that Desdemona's system of thoughts is composed of moral-binding values that offset Renaissance restrictions:

Table 4. Desdemona's conceptual account of ethics

\begin{tabular}{ll}
\hline Reference & Conceptual Metaphor \\
\hline I see a divided duty (1.3.181) & DUTY IS A DIVISBLE OBJECT \\
But what praise couldst thou bestow on a deserving woman indeed, one that in the & HONESTY IS POWER \\
authority of her merit did justly put on the vouch of very malice itself? $(2.1 .142-45)$ & REPUTATION IS A GARMENT * \\
If I have any grace or power to move you his present reconciliation take (3.3.47-48) & POWER IS SELF-PROPELLED MOTION \\
& PASSIVITY IS INABILITY TO MOVE * \\
My downright violence and scorn of fortunes may trumpet to the world (1.3.250-252) & SELF-DETERMINATION IS PHYSISCAL STRENGHT \\
& SELF-DETERMINATION IS NARURAL FORCE * \\
If I do vow a friendship, I'll perform it to the last article (3.3.21-22) & ACTIONS ARE PERSONS * \\
\hline
\end{tabular}

Desdemona sets standards of moral values through which she sees and acts in the world. Knapp (2011) advances the concept that "for Shakespeare, the fraught relationship between what we see and what we do is a condition of ethical agency" (p. 160). Actually, Desdemona reconciles between what she sees and how she behaves. Because she identifies duty as a divided object, she is able to recognize it as the sum of multiple alternatives for her loyalty and choice. Thus, she opts to follow her husband and not her father. In The Right and the Good, W.D. Ross proposes the idea that if the individual is faced with two conflicting duties then the duty that is most "incumbent to the circumstances of the case" (p. 19) supplants the other one. The idea that duties are conditional is what allows Desdemona to remain faithful to her commitment to Cassio in spite of Othello's recurring wrath and mistreatment. By conceptualizing their friendship in terms of a political and legal treatise, Desdemona confers a compulsory and authoritative aspect to her vows and pledges in helping him reinstate his Lord's favour.

The concepts, HONESTY IS POWER and REPUTATION IS A GARMENT, dissociate Desdemona's vision of ethics. Despite the protagonist's occasional omissions and lies about the handkerchief, which may be considered a defence mechanism against Othello's unbridled violence, honesty for the female protagonist is a given token of authority, a matter not of excess or defect, but of her nature. In fact, even though these concepts are delivered to overthrow Iago's derogatory classification of women, Desdemona seems to implicitly associate to her character two traits: deserving and merit. In the context of the Renaissance, Gollapudi (2011) argues that "at a time when the link between visibility and moral discipline was becoming pervasive, the role of the female gaze is defined as that of deliberate indirection" (p. 105). Moral behaviour is the basis of social interaction. By claiming that she is worthy of social praise and recognition for her moral merit, Desdemona does not only claim visibility but also moral agency. Through this public assertion of the ability to construct moral judgement, Desdemona circumvents the expectations of a closed masculine world in her congenial appreciation of self-worth.

In a memorable passage with Iago, Cassio laments "reputation, reputation, reputation! $O$, I have lost my reputation! I have lost the immoral part of myself, and what remains is bestial. My reputation, Iago, my reputation" (2.3.249-251). The Renaissance was a culture that meted public punishments for private transgressions, parading adulterous wives and putting bridles on nagging spouses. The image of the self in the 
eyes of the other came to define the individual in a convoluted amalgamation between a collective consciousness and private conduct. Regarding women's reputation, the Renaissance funnelled an obsession with chastity. Juan Louis Vives writes "in a woman, no one requires eloquence or talent or wisdom or professional skills or administration of the republic or justice or generosity; no one asks anything of her but chastity. If that one thing is missing, it is as if all were lacking to a man" (p. 85). Hence, chastity "was not only the leading but the sole index of feminine conduct" (Macleod, 1991). Sixteenth-century Britain summarised the feminine ideal into three icons: the virgin maiden, the abstinent widow, and the faithful wife. The fears of being a gulled father or a cuckolded husband came to be evaluators of female morality; a morality that is compromised by the limitations of social interpretation of female reputation. Ironically, Desdemona violates all of these codes since the beginning of Othello.

Yahri-Milo (2018) comments that "fighting for vital interests involves fighting to secure certain material stakes, irrespective of the reputational considerations involved" (p. 30). Desdemona's vital interests are to secure happiness and freedom. Her elopement with Othello is a challenge to the social rituals of marriage that consecrates the transference of duty to the husband through paternal consent. Her choice to trespass into politics when she sails on warfare with her husband flaunts Renaissance feminine ideals of temperance and fortitude. The material stake that she strives to obtain is a marriage based on love and choice "for twas that hand that gave away my heart" (3.4.40).

The concept REAPUTATION IS A GARMENT comes to reflect Desdemona's awareness that she embarks in the world of the play with an already 'tarnished reputation'. Weiner and Schneider (1989) argue that "complex moral and ethical issues of dominance and autonomy, opulence and poverty, continence and sexuality, find ready expression through cloth" (p. 2). Hence, one might deduce that reputation, which is a social construct, can be associated with clothes. Clothes are a mask that can conceal and hide identities making it arduous to distinguish between authentic innocence and forged morals. For Desdemona, the softness of materials that make up clothes reflects the fragility of a person's reputation which can unravel as easily as the threads of a fabric. Ironically, she seems to echo Iago's belief that a "reputation is an idle and most false imposition" (2.3.250).

The concept, POWER IS SELF PROPELLED MOTION, maintains Desdemona' belief that power is located within the self. Patriarchy cannot grant or deprive her from what it does not own. Power is self-generated and self-entertained by the individual himself. Free action becomes uninhibited. The conclusion that passivity is the inability of movement further emphasizes the illusory nature of the shackles and walls that a patriarchal society implements to convince Desdemona of her physical and moral impairment. This vision is cemented by her concepts, SELF-DETERMINATION IS PHYSICAL STRENGTH, SELF-DETERMINATION IS NATURAL FORCE, and ACTIONS ARE PERSONS. Desdemona defines her choices and actions as world changing factors. Lakoff considers that "actions do not continue to exist after they occur" (200). Through the personification of her actions, Desdemona secures their existence after being performed. Her subjectivity is concretized. Her rebellion against father and culture becomes a self-proclaimed physical reality that gains the attributes of the action itself; blatant, violent, and scornful.

\section{Desdemona's Scope of Agency}

In the play, Desdemona is doomed to die for her rebellion. Her fate is sealed once she chose to "profess due to the Moor my lord" (1.3.188) against all social norms and expectations. Towards the end of the play, Ludovico mystifies her demise into a nameless act "till that the nature of your fault be known to the venetian state" (5.2.336-337). His words intimate a certain sense of impunity for her murder. Indeed, disobedient daughters must be banished for putting their fathers "in impatient thoughts" (1.3.243) and willful wives must be eradicated for merely "shrewd doubt" (3.3.431). However, Desdemona makes a cognitive leap over normative definitions and standards. She becomes the epitome of Jin Ko and Shurgot observations that in Shakespeare the characters are "free artists of themselves, continually overhearing themselves and reinventing themselves with an introspective consciousness" (5). Indeed, the analysis of Desdemona's conceptual metaphors allows for the inception of a female character who monopolizes empathy and achieves self-actualization.

Conceptual Metaphor analysis allows for the immergence of a heroine who commanders empathy on stage by emotionally imprinting on the audience's cognitive space. Examining the tables above, Desdemona's conceptual metaphors aggregate in three major instances in the play: the Senate scene in the first act, the beginning of tension between the spouses in act three, and the violent clash between a jealous Othello and Desdemona in act four. Her conceptual metaphors become increasingly sparse and absent as she is smothered into silence in the final scene of the tragedy. Zlatev (2012) explains that "in moving ourselves, we move others; in observing others move - we are moved ourselves" (p. 2). In these turbulent occasions, she loads the cognitive space of the stage with emotional 
bursts, even though she fails to move Othello. The target of her conceptual metaphors is not the hero but rather the actual audience, holding their attention by the force of the unsaid and promoting retention and recall. All the efforts to abort her words in what follows are supplemented by her previous transference of ideas and thoughts to the audience.

In the same vein, Charteris-Black (2004) suggests that the "analysis of metaphor is often, then, an exploration of the inner subjectivity of speakers - what it is unique to their perception of the words" (p. 11). At the beginning of the tragedy, both Brabantio and Othello urge Desdemona to speak. Both were eager to hear her story which each believed to be in his favor, only to be disgraced once her advocations are deemed out of tune. Her voice is interrupted not only through death but also through the suffocating words of Iago and Othello. Within an overarching allegory of patriarchal narratives, Desdemona's concepts of the feminine body and voice, emotions, and ethics are metaphoric stories of a distinct individual. She becomes the bearer of a shadow story in the play. Abbott (2015) describes shadow stories as "unnarrated, they are tendrils of story that generally hook onto parts of the text $[\ldots]$ they are rather sensed possibilities" (p. 104). Desdemona discards the literal in favor of the allegorical, since her words are possible yet incompatible in the world of the play. She embeds her own story within others' stories. Consequently, her conceptual metaphors "open on a vast arena of virtual events that are never realized but rather exist like a kind of dark, weightless energy, hidden under the words and images that actualize a story" (Abbot, 2015). They shed light on these fleeting tendrils of Desdemona's supposedly incomplete text. Conceptual metaphors become a tapestry that unfolds cognitively, ripe with clandestine tales.

Desdemona's expression of subjectivity is translated in the tensions between the symbolic order in the play and the heroine's own mental space of self-perception. Charteris-Black (2004) suggests that "If language is a prime means of gaining control of people, metaphor is a prime means by which people can regain control of language and create discourse" (p. 253). In the Renaissance, patriarchy has claimed the privilege to name and to define. Desdemona agitates these normative foundations when she rearranges cultural definitions of womanhood; the body is celebrated, emotions are a source of knowledge, and women are endowed with morality. Conceptual metaphor theory becomes a technique of subtle criticism of external forces that want to infringe upon her inner autonomy. Resistance takes shape when the material and the affective are franchised from an insular social discourse. The nature of conceptual metaphors itself threatens to topple stable monolithic significations. The infinite possibility of interpretations of Desdemona's words and intensions dispels any attempts to restrain her existence into a predictable and unique signified.

\section{Conclusion}

All things considered, Desdemona reflects a complex Shakespearean character where emotions, subjectivity, and power are intimately intertwined in her system of thoughts. The analysis showed how the heroine's mental schemata dissolve the restraints of patriarchy. In her mind, the body is putative. Emotions are heuristic and ethics are idiosyncratic. She claims an ethical code of her own against morally dubious social expectations when it comes to women. Her identity is celebrated while being defiled and challenged by patriarchal laws. She reconciles irreconcilable Renaissance values: emotions and reason, desire and ethics, women and dissidence. Therefore, even though her access to agency remains tortuous, it is a cognitive journey that she embarks on in the play. She intrudes upon the male sphere by insisting to follow Othello to battle. She seeks political activism when she interferes with Othello's martial decisions even though it causes her to stand "within the blank of his displeasure" (3.4.120). She engages within the quiet and subtle register of female action through conceptual metaphors. To read Desdemona as a complete character, one needs to factorize all the previous conclusions and assumptions.

Finally, Desdemona's tragic journey resides in her sense of shared trauma with Othello. Both are social rejects. He is the victim of racism. She is the victim of sexism. Symbolically, their marriage is an alliance of wills against prejudice, a frontline of resistance and challenge. Yet, unlike Othello whose existential and sexual anxieties deepen, Desdemona frees herself from patriarchy. She cannibalizes his stories in her mind and grafts them to her identity as Othello himself comments "she wished that heaven had made her such a man" (1.3.164). Conceptually, Desdemona usurps power. She becomes the warrior and the adventurer in her own metaphoric stories. Her marginalization becomes strength instead of a weakness. By committing her first act of defiance in liberating her body from patriarchal custody, Desdemona overcomes trauma and reconstructs her femininity in her own terms.

\section{References}

Abbott, P. (2015). How Do We Read What Isn't There to Be Read? Shadow Stories and Permanent Gaps. In L. Zunshine (Ed.), The Oxford Handbook of Cognitive Literary Studies (pp. 85-103). Oxford: Oxford University Press.

Aristotle. (2004). Rhetoric. New York: Dover Publications INC. 
Barker, F. (1995). The Tremulous Private Body: Essays in Subjection. USA: University of Michigan Press. https://doi.org/10.3998/mpub.9516

Baumlin, T. (2009). Criritcal Responses and Approaches to British Relassance Literature. In S. Bruce \& S. Rebecca (Eds.), The Renaissance Literature Handbook (pp. 134-155). London: Continuum.

Belsey, C. (1985). The Subject of Tragedy: Identity and Difference in Renaissance Drama. New York: Routledge.

Charteris-Black, J. (2004). Corpus Approaches to Critical Metaphor Analysis. UK: Palgrave Macmillan. https://doi.org/10.1057/9780230000612

Clarke, M. C. (1887). The Girlhood of Shakespeare's Heroines. A. C. Armstrong \& Son.

Drakakis, J. (1992). Shakespearean Tragedy. New York: Taylor \& Francis.

Evans, D. (2015). Language and Identity: Discourse in the World. London: Bloomsbury.

Fludernik, M. (2010). Naturalizing the Unnatural: A View from Blending Theory. Journal of Literary Semantics, 1-27. https://doi.org/10.1515/jlse.2010.001

Fowler, R. (1996). Linguistic Criticism. Oxford Univeristy Press.

Fox, C. (2013). Blazons of Desire and War in Shakespeare's Troilus and Cressida. In S. Morrison \& U. Deborah (Eds.), Staging the Blazon in Early Modern English Theatre (pp. 198-221). London: Routledge.

Freeman, D. C. (1993). According to my bond: King Lear and Re-cognition. Language and Literature: International Journal of Stylistics, 2(1), 1-18. https://doi.org/10.1177/096394709300200101

Freeman, D. C. (1995). Catch[ing] the nearest way: Macbeth and cognitive metaphor. Journal of Pragmatics, 24(6), 689-708. https://doi.org/10.1016/0378-2166(95)00015-K

Freeman, D. C. (1999). The Rack Dislimns: Schema and Metaphorical Pattern in Antony and Cleopatra. Poetics Today, 20(3), 443-460.

Gollapudi, A. (2011). Moral Reform in Comedy and Culture 1696-1747. Burlington: Ashgate.

Karim-Cooper, F. (2006). Cosmetics in Shakespearean and Renaissance Drama. Edinburgh: Edinburgh University Press. https://doi.org/10.3366/edinburgh/9780748619931.001.0001

Kelso, R. (1956). Doctrine for the Lady of the Renaissance. University of Illinois Press.

Knapp, J. (2011). Image and Ethics in Shakespeare and Spencer. New York: Palgrave. https://doi.org/10.1057/9780230117136

Ko, Y. J., \& Michael, W. (2016). Shakespeare's Sense of Character: On the Page and From the Stage. London: Routledge.

Kovecses, Z. (2003). Metaphor and Emotion: Language, Culture, and Body in Human Feeling. Cambridge Univeristy Press.

Kovecses, Z. (2010). Metaphor: A Practical Introduction. Oxford University Press.

Kovecses, Z. (2020). Extended Conceptual Metaphor Theory. Cambridge University Press. https://doi.org/10.1017/9781108859127

Lakoff, G. (1987). Women, Fire, and Dangerous Things. Chicago: University of Chicago Press.

Lakoff, G. (2006). Conceptual Metaphor: The Contemporary Theory of Metaphor. In D. Geeraerts (Ed.), Cognitive Linguistics: Basic Readings (pp. 185-238). Berlin: Mouton de Gruyter. https://doi.org/10.1515/9783110199901.185

Lakoff, G., \& Mark, J. (1980). Metaphors We Live By. University of Chicago Press.

Loomba, A. (1989). Gender, Race, Renaissance Drama. Manchester University Press.

Mailloux, S. (1989). Rhetorical Power. Ithaca: Cornell University Press. https://doi.org/10.7591/9781501728426

McDermott, J. (2014). There's Magic in the Web of It. In L. Johnson, S. John \& T. Evelyn (Eds.), Embodied Cognition and Shakespeare's Theatre: The Eraly Modern Body-Mind (pp. 154-172). London : Routledge.

McLeod, G. (1991). Virtue and Venom: Catalogs of Women from Antiquity to the Renaissance. University of Michigan Press. https://doi.org/10.3998/mpub.9690632

Morrison, T. (2012). Desdemona. London: Oberon Books. 
Oncins-Martinez, J. (2007). Shakespeare's Sexual Language and Metaphor: A Cognitive-Stylistic Approach. In M. Ravassat \& C. Jonathan (Eds.), Stylistics and Shakespeare's Language: Transdisciplinary Approaches (pp. 215-245). New York: Continuum

Ortony, A. (1993). Metaphor and Thought. UK: Cambridge University Press. https://doi.org/10.1017/CBO9781139173865

Paris, B. (2009). Bargains with Fate: Psychological Crises and Conflicts in Shakespeare and His Plays. New Jersey: Transaction Publishers.

Paster, G. K. (2004). Humoring the Body: Emotions and the Shakespearean Stage. University of Chicago Press. https://doi.org/10.7208/chicago/9780226648484.001.0001

Pickavé, M., \& Lisa, S. (2012). Emotion and Cognitive Life in Medieval and Early Modern Philosophy. Oxford English Press. https://doi.org/10.1093/acprof:oso/9780199579914.001.0001

Rose, M. B. (2002). Gender and Heroism in Early Modern English Literature. University of Chicago Press.

Ross, W. D. (2002). The Right and the Good. Oxford University Press. https://doi.org/10.1093/0199252653.001.0001

Schwarz, R. (1997). Metaphors and Action Schemes: Some Themes in Intellectual History. Bucknell Univerity Press.

Semino, E., \& Gerard, S. (2008). Metaphor in Literature. In R. W. Gibbs (Ed.), The Cambridge Handbook of Metaphor and Thought (pp. 232-246). Cambridge University Press. https://doi.org/10.1017/CBO9780511816802.015

Shakespeare, W. (2005). Othello. Yale University. https://doi.org/10.1017/9780511812453

Sinfield, A. (1992). Faultlines, Cultural Materialism and the Politics of Dissident Reading. Los Angeles: University of California Press.

Slater, M. (2019). Desdemona's Divided Duty: Gender and Courtesy in Othello. In P. Akhimie \& A. Bernadette (Eds.), Travel and Travail: Early Modern Women, English Drama, and the Wider World (pp. 215-239). University of Nebraska Press. https://doi.org/10.2307/j.ctv8xnh57.17

Stallybrass, P. (1982). Macbeth and Witchcraft. In J. R. Brown (Ed.), Focus on Macbeth (pp. 190-201). New York: Routledge.

Stockwell, P. (2002). Cognitive Poetics: A New Introduction. London: Routledge.

Stone, L. (1990). The Family, Sex, and Marriage in England 1500-1800. Penguin Books.

Stroud, B. (2018). Seeing, Knowing, Understanding. UK: Oxford University Press. https://doi.org/10.1093/oso/9780198809753.001.0001

The New Testament (Trans. by H. T. Anderson). Louisville: John P. Morton \& Company, 1866.

Vaught, J. (1866). Masculinity and Emotion in Early Modern English Literature. Burlington: Ashgate.

Vives, J. L. (trans Charles, F.) (1540). The Education of Christian Woman: A Sixteenth-century Manual. University of Chicago Press.

Wehrs, D. R. (2017). Introduction: Affect and Texts: Contemporary Inquiry in Historical Context. In T. Blake \& R. W. Donald (Eds.), The Palgrave Hngadbook of Affect Studies and Textual Criticism (pp. 1-94). Palgrave Macmillan. https://doi.org/10.1007/978-3-319-63303-9_1

Weiner, A. B., \& Jane, S. (1989). Cloth and Human Experience. Washington: Smithsonian Books.

Yarhi-Milo, K. (2018). Who Fights for Reputation: The Psychology of Leaders in International Conflict. Princeton University Press. https://doi.org/10.23943/9781400889983

Zlatev, J. (2012). Bodily Motion, Emotion, and Mind Science. In F. Ad, L. Ulrike, R. Timothy \& Z. Jordan (Eds.), Moving Ourselves, Moving Others: Motion and Emotion in Intersubjectivity, Consciousness, and Language (pp. 1-28). John Benjamins Publishing Company. https://doi.org/10.1075/ceb.6.01zla

\section{Copyrights}

Copyright for this article is retained by the author, with first publication rights granted to the journal.

This is an open-access article distributed under the terms and conditions of the Creative Commons Attribution license (http://creativecommons.org/licenses/by/4.0/). 